\title{
Populist tactics and populist rhetoric in political parties of Post-Soviet Russia
}

\author{
Yuri Korgunuyuk \\ Doutor em Ciência Política \\ Analista político do Information Science for Democracy - INDEM Foundation \\ Moscou, Rússia \\ partinform@mail.ru
}

\begin{abstract}
The article of Yu. Korguniuk (Russia) is devoted to various appearances of populism in tactics and rhetoric of political parties in post-Soviet Russia (since 1990). The author discusses these appearances in activities both of political parties which may be called populist without a shadow of doubt, and parties which use populist tactics and populist rhetoric but cannot be considered populist in the full sense of the word. To his opinion, populism in post-Soviet Russia has some features similar to Latin American populism and some which distinguish it from the latter. The common characteristics are charismatic leadership, political personalism, priority of leadership over institutions, adherence to national development concepts and anti-globalization movement. The difference lies in the interpretation of 'anti-imperialism': the Russian populism is anti-American and anti-Western but not anti-imperialist in general. Russian populists are, as a rule, extreme Russian imperialists and, to a certain degree, nationalists. The Russian populism also may be called statist and paternalistic: there is almost no difference between left (socialist) and right (nationalist and conservative) populisms in Russia. Besides, the author argues that many traditional ideologies - such as communism and nationalism - are, in fact, varieties of 'state populism' in today's Russia. He concludes that populism have embraced the whole Russian political spectrum, including even those sectors which have always positioned themselves as anti-populist.
\end{abstract}

Key words: Post-Soviet Russia, political parties, populism.

$\mathrm{R}$ USSIA DID NOT KNOW EITHER CLASSICAL POPULISM or neopopulism. When the first wave of populism overflowed Latin America, the Soviet Union lived under the communist dictatorship which implemented the concept of people's sovereignty only verbally in practice, it differed from other dictatorships only by its cruelty and totality.

The rebirth of real politics in Russia was accompanied by the appearance of some kind of populist tactics and populist rhetoric. The largest anticommunist civil and political association of the late Soviet epoch - the Democratic Russia Movement - did not shy away from populism. Russian researchers N. Biriukov and V. Sergeiev defined DR as 'a strange alliance of liberals and populists' in which 'the latter easily pushed back the former'. ${ }^{1}$ This opinion was close enough to assessments given by Democratic Russia's leaders themselves. For example, member of DR's leadership Vladimir Bokser recognized that Democratic Russia was an alliance of committed democrats, successors of academician 
Sakharov on the one hand, and populists on the other. According to him, thanks to this alliance a narrow circle of liberal intellectuals were able to inject democratic ideas into the population at large. ${ }^{2}$ In 1991, Sergei Mitrokhin, then a political analyst and now the leader of the Yabloko party, mentioned 'ability to use populist methods of political pressure and propaganda' among Democratic Russia's virtues. ${ }^{3}$

But it should be noted that all these researchers and politicians understood 'populism' as promises to solve complicated problems by simple methods. In those times, democrats saw the transition to the free market economy as a kind of magic solution. They supposed that when the transition is made, all problems will be solved almost automatically. The reality appeared to be much more complicated. But in the early 1990s most democrats believed it quite sincerely. And this is why it would be somewhat inaccurate to characterize Democratic Russia followers as populists.

Therefore, it is necessary to define what kind of tactics and rhetoric we consider populist. The problem is that some characteristics of the Latin American populism are not applicable to the Russian situation. For example, we can speak about anti-imperialism of the Russian populists only if the United States is seen as the world's only empire. In this regard, most of the Russian populists are anti-imperialist. But they are extreme imperialists when it comes to imperialism in general. They dream of restoring the Soviet Union (or the Russian Empire within the limits before 1917) and even to expand its possessions more and more.

Besides, it seems insufficient to interpret populism as prioritizing ordinary people's interests over the elite's interests, as legitimization of the populace and de-legitimization of the elite. ${ }^{4}$ There are almost no political forces in post-Soviet Russia which would declare that they defend rich and strong people against poor and weak ones.

In this paper we will call populists those politicians who strive to increase their popularity by all means, who are ready to give any promises to any voters so as to obtain their support. For us, a populist is a politician who is not embarrassed by the fact that their promises to one voter contradict the promises given to another voter. Or, more simply put, a 'populist' is an euphemism for unprincipled demagogue who consciously appeals not to sophisticated intellectuals but to the people in the street, in the hope that the latter are not competent enough and do not understand that they are trying to deceive them. Maybe this is not a very clear-cut definition but it works while describing the Russian situation.

In this paper we will discuss Russian political parties which may be called populist without a shadow of a doubt as well as those parties which use populist tactics and populist rhetoric but cannot be recognised as populist in the full sense of the word.

\section{Populist parties}

While speaking about populist parties in post-soviet Russia, four parties should be mentioned in the first place: the Liberal-Democratic Party of Russia (LDPR), the People's Republican Party of Russia (PRPR), Rodina (Motherland) party and the Russian Party of Pensioners (RPP). The pioneer of populism in Russia was surely the LDPR.

\section{The Liberal-Democratic Party of Russia.}

Many researchers classify the LDPR as nationalists. ${ }^{5}$ We can agree with this, given that the party adheres to rigid conservative and imperialist positions. But it is also necessary to take into account that nationalists are understood in present-day Russia as proponents of ethnic nationalism and racism first of all. Parties of such orientation are called 'right extremists', 'fascist', and 'neo-fascist' in Western democracies. ${ }^{6}$ The LDPR likes to present itself as the chief champion of the Russian people, but it had very tense relations with ethnic nationalists because, at least, of the Jewish origin of its leader Vladimir Zhirinovskii. The LDPR's hobbyhorse is rather grotesque conservative populism, which means the cult of Power. In Zhirinovskii's interpretation, restoration of Russia as a military superpower should automatically increase the well-being of the population, ensure high salaries and pensions, among other things, to the people.

The LDPR appeared in the Russian political scene at the end of 1989 and owes its origin and existence exclusively to its leader - to his ambitions, charisma and showman abilities. V. Zhirinovskii never restricted himself when promising. During the presidential campaign of 1991, he pledged to restore economic prosperity in two or three years through liber-

2. V. Boxer's speech at a plenary session of the Representative Council of Democratic Russia. September 14-15, 1991. - The Central Archive of Social and Political History of Moscow, f. 8651, op. 1, d. 21, I. 73.

3. Mitrokhin (1991).

4. Musikhin (2009, p. 48-49).

5. Yang, Launer, Likhatchiova, Williams, Ishiyama (1997); Golosov (1999); Sakwa (2000).

6. Sakwa (2000, p. 217). 
alization of economic activities of all kinds, complete refusal of economic assistance to other countries, repayment or assignment of external debts to Russia. $^{7}$ According to some mass media, while speaking before voters, Zhirinovskii promised to give a man to every woman and a bottle of vodka to every man.

V. Pribylovskii, one the first chroniclers of the new Russian political parties, had for a long time referred the LDP to the class of midget parties, ${ }^{8}$ and there were serious grounds for such a classification. In 1991, the LDP did not have enough resources to collect 100,000 voter signatures for nomination of its leader as a presidential candidate. Zhirinovskii had to ask the Congress of People's Deputies of the RSFSR to permit him to run at the election. When deputies from Democratic Russia stated that they had not seen any LDP branches in any Russian town, and called the party a 'bluff' and a 'bubble', Zhirinovskii responded with both bluster ("the LDPR has 17 thousand cells from Moldavia to Kamchatka') and a reasonable objection ('The party's power is shown up by the number of votes, not of members" ${ }^{\text {' }}$ - here he was close to the truth).

The democrats' hostile attitude toward Zhirinovskii had deep roots. They treated him as an agent of the Kremlin, the Communist Party and the KGB, and they had good grounds for saying it. The LDP was the first party registered by the Ministry of Justice of the Soviet Union in April 1991 (it was then called the LDP of the Soviet Union; 'the LDP of Russia' name appeared in 1992). Zhirinovskii fiercely criticized democrats for their willingness to destroy the USSR, and participated actively in the Kremlin's projects, such as the creation of the puppet 'Centrist Bloc of Political Parties and Movements' in 1990, the aim of which was to discredit the idea of freedom of association and to disorientate public opinion the Bloc positioned itself as a 'third force', the golden mean between the Communist Party and Democratic Russia.

At that time, nobody treated Zhirinovskii as an independent actor. This attitude didn't change even after Zhirinovskii came third in the presidential election in June 1991 (7.8 percent of votes; the first was Boris Yeltsin with 57.3 percent, the second - Nicolai Ryzhkov, the former prime minister of the USSR, with 16.85 percent). The situation changed only after the LDPR's sudden triumph in the 1993 parliamentary election; the party got more votes by party list than any other participant, that is, 22.92 percent. This suc- cess triggered fast growth of the party's membership. Previously the LDPR's structure had existed mainly on paper, but now party branches appeared on regional as well as on local levels. Zhirinovskii's followers formed factions in many regional legislatures in 1994-1995.

However, the LDPR received only 11.18 percent by party list at the 1995 parliamentary election, losing half of its electorate, most probably to the Communists. After that, the party began to lose its members and local organizations. According to G. Golosov's calculation, in the second half of the 1990s the LDPR took part in most regional elections, but won representation only in four legislatures. ${ }^{10}$ At the 1999 parliamentary election, the LDPR barely cleared the five-percent threshold (5.98 percent), and many observers decided that the LDPR lived its last days. But Zhirinovskii proved that analysts were wrong in counting him out. His party received 11.45 percent of votes in 2003 and 8.14 percent in 2007. Besides, LDPR got representation in most regional legislatures in 2008-2010.

The secret of LDPR's successes always intrigued political analysts. Most of them came to the conclusion that the main reason lies in Zhirianovskii's brilliant abilities as a political showman and his close ties with the Kremlin, which used him for controlling a significant part of the protest electorate. But we can also say that the main factor behind Zhirinovskii's victories was his extreme populism. The necessity to give unrealizable promises and to contradict himself at every step never embarrassed him. In the same speech he could call himself an adept of free and wide discussion and demand abolition of the freedom of press and establish the 'rigid vertical of authority'. He swore allegiance to traditions and displayed 'advancedness' rare for people of his age, when calling for the legalization of prostitution and 'light drugs'. He advocated 'the restoration of the Russian State within the boundaries of the Soviet Union' and at the same time demanded to cease 'any aid in any direction'. He stood for lifting restrictions on all kinds of economic activities and abolishing most taxes and, at the same time, for strengthening the public sector. Zhirinovskii promised to eradicate all organized crime and included persons with doubtful reputation into the party lists.

As to the program of the LDPR, it was a mixture of contradictory postures. One can agree with V. Sheinis, who noted: 'It makes no sense to analyze

7. Rossiiskaia Gazeta, 11/6/1991.

8. Pribylovskii (1991, p. 17).

9. Chetviortii S'ezd Narodnykh Deputatov RSFSR. 21-25 Maia 1991 g. Stenograficheskii Otchiot. Moscow.: Izdanyie Verkhovnogo Soveta RSFSR, 1991, v. 1, p. 122-123, 129, 183

10. Golosov (2006, p. 80). 
the program and ideological stances with which the LDPR goes to the voter. Zhirinovskii is a perfect example of a chameleon politician who chooses the political color that seems to him the most appropriate at the given moment, and easily changes his position in any direction'. ${ }^{11}$ Such a position is exactly what we call populism. It should be noted that Zhirinovskii's populism is populism of a special kind. It's 'statist populism' and even 'imperialist populism'.

What the LDPR has in common with nationalists and communists, is the cult of the State as a great military power. But the 'Zhirinovskii's statism is free of traditionalism; it is rather a lumpen's admiration of pure force. In his interpretation, statism seems especially attractive to many voters because it does not demand any payment - no 'guns before butter'. On the contrary, according to Zhirinovskii, the restoration of a mighty military superpower in Russia would increase well-being automatically and provide people with high salaries and good pensions, among other things. According to his statements at the 1993 election, it was sufficient to suspend conversion of the defense industry, continue to produce and export weapons - and 30-percent economic growth was guaranteed for Russia. ${ }^{12}$

The success of the LDPR at the 1993 election generated plenty of imitators who tried to exploit slogans of the 'statist populism'. The names of new parties which appeared in 1994-1995 are self-evident: the Power Party, the 'Rebirth of Power' Movement, the Social-Patriotic Movement 'Power'. Nevertheless, none of them was able even to come close to LDPR's success, not to speak of repeating it. The most successful of them - the Congress of Russian Communities, which had charismatic General A. Lebed in its party list - failed to overcome the five-percent threshold at the 1995 election (4.31 percent).

But the 1996 presidential campaign showed that not only Zhirinovskii could exploit slogans of 'statist populism' successfully.

\section{General A. Lebed and his organizations.}

In 1992-1995, General Alexander Lebed was the commander of the Russian troops in Transnistria (a self-declared republic in the territory of Moldova), where he enjoyed wide popularity among the local residents. Thanks to attention by Russian mass media, his popularity grew in Russia as well. Lebed resigned in 1995 and went into politics. He formed the move- ment Honor and Motherland and agreed to take the third position in the party list of the Congress of Russian Communities. Many experts suppose that one of the reasons; why the CRC did not overcome the five-percent threshold at the 1995 parliamentary election; was that A. Lebed was not n. 1 but only n. 3 .

When Lebed ran at the 1996 presidential election, his success was much more impressive. He came in third place in the first round (14.52 percent), losing only to the incumbent president B. Yeltsin (35.28 percent) and the Communist Party leader G. Ziuganov (32.03 percent). Lebed campaigned in a pure populist style. His platform was a mixture of statist and liberal ideas. He criticized the methods and results of the free market reforms but did not deny their necessity. Lebed said: 'The state, bureaucracy subjugated society and the market and deformed them. It's necessary for society to change the state. ...The real transformation of the country must begin with the transformation of the state, with the cleanup of the state. ... It's necessary not to build a free market economy in line with the present bureaucratic machine but, on the contrary, to bring the bureaucratic machine in accordance with the free market economy and free society.'. ${ }^{13}$

The central point of Lebed's message was: 'If there is a man at the head of the state who isn't linked to the 'nomenklatura', who understands clearly what should be changed and how it should be changed, who has strong will and who won't be bought or intimidated, then a chance will appear that there will be order in the state affairs, the market of bribes will disappear, and the real market economy will be built'. ${ }^{14}$ Surely, it was presupposed that only Lebed could be such a man.

Lebed's program of action was very simple and attractive for the people in the street. He pledged to set the Russian economy free of 'bureaucratic and criminal grip'. The first step, Lebed said, was to arrest all organized crime bosses, the second - to cut down taxes and reduce the bureaucratic apparatus (as a result, the field for bribes would be diminished), the third - to create debtors' prisons ('Unfair bankrupts, persistent defaulters on wages and taxes, will be subject to criminal prosecution'). 'After these measures are undertaken, Lebed promised, an economic boom will start in Russia.' ${ }^{15}$

As it became known later, the presidential administration supervised Lebed's campaign. It provided him with rich sponsors, TV airing and capable speechwriters. But Lebed's charisma, his soldierly humor

\footnotetext{
11. Sheinis (2005, p. 658).

12. Zhirinovskii's message to LDPR's members and sympathizers (November 1993), PartArchive Database (http://www.indem.ru/pa98/).

13. Izvestia, 31.05.1996. 
and his seeming simplicity contributed much to his success as well.

Between the first and second rounds, Lebed accepted the proposal to become the secretary of the Security Council and the national security assistant to the president, and after that he called his supporters to vote for the incumbent president. Lebed was able to do some important things before his dismissal in October 1996, including signing a peace agreement with insurgent Chechnya. The popularity resource, earned by Lebed in those months, was sufficient to establish several political organizations: For Truth and Order bloc, The Third Force alliance and, last but not least, the People's Republican Party of Russia.

Those organizations formulated their tasks in the spirit of the 'statist populism': 'strengthening the Russian statehood', 'revival of united and indivisible renovated Russia', 'development of patriotic solidarity of citizens, their moral dignity, legal and national self-consciousness', 'helping compatriots abroad and non-governmental associations in the CIS that stand for integration with Russia', 'opposing those who undermine the national security of the country', 'facilitating formation of a social safety net in order to strengthen the family, help distressed people, provide them with education and health care'. ${ }^{16}$

As N. Petrov wrote, the main points of Lebed's ideology (so called 'common sense ideology') represented 'an extravagant mixture of criticism of the existing order of affairs from the "common oppositional" point of view, some abstract slogans and ideas of utopian socialism, references to Lebed's personal experience in preventing ethnic conflicts, and Lebed's "brand" aphorisms'. ${ }^{17}$ Yu. Shevtsov, Lebed's assistant in the Honor and Motherland movement and in the People's Republican Party of Russia, frankly expressed the essence of the RPPR ideology: 'We have no need to be uncomfortable about the fact that our party has emerged not as a party with a clearly articulated ideology but as a party that follows its leader. Our fellow citizens found that Alexander Ivanovich [Lebed] was a man who was able to make government serve the people. They found that he was able to return honor and truth, common sense and order into Russian politics.' ${ }^{18}$ So, Shevtsov admitted that his party was a party of charismatic leadership and thus highlighted its populist nature.

Lebed's followers ran successfully at some regional elections in 1996-1998. For example, Alexei Lebed, the general's younger brother, won the election for governor in Khakassia (December 1996). The general himself became the governor of Krasnoyarsk Krai (May 1998). Besides, representatives of the PRPR and Honor and Motherland movement, merging into electoral blocs called The Third Force, formed groups in several regional legislatures (Krasnoyarsk Krai, Novosibirsk Oblast, Ivanovo Oblast, Tomsk Oblast, Irkutsk Oblast, and others). Lebed's adherents also were elected mayors of some large cities; the brightest examples were Samara and Nizhniy Novgorod.

Nevertheless, after Lebed became the governor, he stopped to handle his party's matters. This was fatal for his followers. Left without oversight, they plunged into internal strife and brought the People's Republican Party of Russia and other Lebed's organizations to fast decline. As a result, by 1999 the party was too weak to run at the parliamentary election. Lebed's death in a helicopter crash (2002) finished off the last hopes of his party followers.

\section{Rodina (Motherland) bloc and party}

Another successful populist project was generated by participants of the Congress of Russian Communities party list at the 1995 election - Sergey Glaziev (the $2^{\text {nd }}$ position) and Dmitrii Rogozin (the $4^{\text {th }}$ position).

The creation of the Rodina (Motherland) bloc began in May 2003, when a group of left conservative organizations authorized Glaziev to prepare a draft agreement on a new electoral coalition. But the Communist Party, to which the appeal was primarily directed, responded with refusal. As a result, the bloc was formed without the CPRF. The first position in the party list of the Rodina bloc was occupied by Glaziev, the second one by Rogozin. The latter looked somewhat alien among his new fellows because six months before he had announced his plan to enter the 'government party' United Russia. Experts considered Rogozin a representative of the presidential administration in the new bloc, and subsequent events confirmed these suspicions.

The Rodina bloc chose tycoons (popularly known as 'oligarchs' in Russia) as the main target of its electoral campaign, and put forward a slogan of nationalization of oil and gas companies. At the beginning of the campaign, the bloc saw United Russia as its main opponent but, after a warning from the presidential administration, ${ }^{19} \mathrm{UR}$ as the "chief en-

16. Charter of the People's Republican Party of Russia, PartArchive Database (http://www.indem.ru/pa98/).

17. Petrov (1999, p. 99).

18. Petrov (1999, p. 104).

19. A phone conversation transcript was published in the Internet. In it Rogozin's interlocutor (supposedly, the assistant head of the presidential administration Igor Sechin) in plain words recommended him to tone down criticism of United Russia (http://www.compromat.ru/page_13665. htm). 
emy' was substituted by the Union of Right Forces, the alliance of adepts of the free market economy. Besides, Rodina leaders actively exploited imperialist slogans. For example, they deliberately played up a conflict between Russia and Ukraine over Tuzla Spit Island in the Black Sea (the Ukrainian authorities tried to artificially extend their state's territory).

The 2003 parliamentary election results proved to be successful enough for Rodina - the bloc got 9.2 percent of votes by party list while its main opponent, the URF, did not overcome the five-percent threshold. Excited by the success, one of Rodina's leaders, S. Glaziev decided to run for president. But here the role of Rogozin as an agent of the Kremlin became evident. He succeeded in nominating ex-chairman of the Central Bank Victor Gerashchenko as the candidate from Rodina. Although the Central Election Commission did not register Geraschenko's candidacy on procedural grounds, Rogozin refused to support Glaziev and called his followers to vote for the incumbent president V. Putin. As a result, the Rodina bloc split into two parts: followers of Rogozin registered Rodina party, while followers of Glaziev tried to register the For Dignified Life movement. As expected, the registration authorities supported Rogozin's project in every way and hampered Glaziev's.

In 2004 , the Rodina party successfully participated in regional elections. It carried out campaigns under populist slogans; United Russia, the government and their 'anti-people' social policy were the main target for its criticism. Another hit topic of Rodina's campaigns was the struggle against 'uncontrolled immigration' of labor force from the former Soviet republics. Nationalist motives grew strong in the party's campaigning, and sometimes they evolved into extreme forms of xenophobia and anti-semitism. For instance, many Rodina representatives signed the notorious 'Letter of 500', which demanded the ban of all Jewish religious and ethnic cultural associations because of their 'extremism'. ${ }^{20}$

Rodina appeared to be close to both kinds of populism - left and right. As the authors of a book about Rodina wrote,

'If we try to define to whom Rodina party is closest, examples can be found just in two places. In Europe, this is the 'new wave' of the right radicalism, politicians anxious about migrants influx and "saving the Nation" in the same degree: Jean-Marie Le Pen (2002), now deceased Pim Fortuyn (2002), Jörg Haider (1999-2002).
In Latin America, there are left populists like Hugo Chávez in Venezuela and Evo Morales in Bolivia who speak out against foreign capital and for the nationalization of "strategic" industries. Such parallels are unlikely to be non-meaningful. Russia really seems like the old European countries in that it also has suddenly faced the problems of maintenance of the cultural identity and socioeconomic stability. And deep distrust in foreign investors and the primary nature of economy bring Russia closer to the Latin American countries which maintain intense relations with the main centers of the world economy (first of all with Europe and North America) and, on the other hand, are not strong enough to make these relations equal. Such conditions and their combination will influence the Russian political life for a long time more. ${ }^{21}$

The most significant shift took place in the beginning of 2005, when inefficient 'benefits monetization' initiated by the government caused dozens of thousands of pensioners to block the roads protesting against depriving them of free travel on municipal transport. Rogozin and his supporters declared that they ceased to be president Putin's 'Praetorian Guard' and passed to opposition (they even staged a hunger strike).

After that, relations between Rodina and the Kremlin deteriorated very much. Since the summer of 2005, regional election commissions began, under the slightest pretext, to refuse to register Rodina branches at elections. If registered, Rodina candidates and lists were stricken from the elections by courts. Rodina could not run at any regional election in the second half of 2005. The presidential administration made it clear that the party should find a new leader. The hint was taken: Rogozin was removed from his post in March 2006 and Alexander Babakov, a businessman more convenient for the Kremlin, substituted him as the party chairman. In the fall of 2006, the party was forced to merge with the Russian Party of Life (RPL) and the Russian Party of Pensioners into Just Russia (JR) party. It is the representatives of the RPL, absolutely loyal to the Kremlin, who occupied the top positions in JR.

\section{The Russian Party of Pensioners}

The history of the Russian Party of Pensioners was right the same. The RPP was founded in 1997 and participated in the 1999 and 2003 parliamentary

20. Evreiskoie schastie, russkyie sliozy (Jewish happiness, Russian tears) in Rus Pravoslavnaia, 3-4 (2005), 1 (http://www.rusprav.org/2005/3-4/1. $\mathrm{htm})$.

21. Mikhailovskaia (2006, p. 47). 
elections: individually in 1999 (1.95 percent by party list), and in coalition with the Party of Social Justice in 2003 (3.09 percent).

The party had an exclusively populist character from the very beginning. The RPP called for among other things, the redistribution of the natural resources rent in favor of ordinary citizens by opening personal accounts and monthly depositing certain amounts in them ${ }^{22}$ and restoring savings in the Sberbank (the main and actually the only bank in the USSR that had handled savings of physical persons). ${ }^{23}$ The party's founder Sergey Atroshenko, a businessman from Tiumen Oblast (Siberia), had the reputation of an adventurer. He unsuccessfully tried to immitate Zhirinovskii' political style.

The situation changed in March 2004 when deputy of the State Duma Valerii Gartung (United Russia) became the new leader of the party. Gartung proved that he was a much more talented populist. He made a tour of the whole country arranging protest actions against the 'benefit monetization' planned by the government. The main slogan of these actions was 'The authorities which deprive the old people of their benefits have no future!'24

As a result, the Russian Party of Pensioners began to obtain good results at regional elections. In 2004, it overcame the five-percent threshold in all regions where it ran. In some regions (Mari El, Khakassia, Koryak Autonomous District, Kurgan Oblast) the increase was several times compared with the results of the 2003 parliamentary election. The most exemplary success was the victory in Tomsk (Siberia) in October 2005 where the RPP got more seats in the municipal council than United Russia.

At the beginning of 2005, V. Gartung supported spontaneous protest actions against the 'benefit monetization' and demanded to dismiss the government. ${ }^{25}$ Just as in the case of the Rodina party, it was a fateful decision for the RPP. First of all, Gartung was expelled from the United Russia faction in the State Duma, then election commissions and courts began to hamper the party's participation in elections.

In Autumn 2005, the former RPP's chairman S. Atroshenko, who had already quit politics and lived abroad, filed a suit against Gartung. He requested to cancel the decision of a party convention (March 2004) on the election of Gartung as the party chairman. The court sustained the claim and suspended Gartung's powers. Later this ruling was invalidated but by that time another party convention (December 2005) had elected the new chairman, Igor Zotov, who was a creature of the Kremlin. The RPP, Rodina party, and the Russian Party of Life merged into Just Russia party in the fall of 2006.

The above-mentioned parties were not only populist organizations in post-Soviet Russia. On the contrary, there were several such parties, but the overwhelming majority of them had too little success. This was the case, for example, of the People's Party of the Russian Federation formed in 2001 on the initiative of the presidential administration. The base of the PPRF consisted of deputies of the State Duma who were elected in single-mandate districts. It seems that the purpose of the party's supervisors in the Kremlin was to create an alternative to the Communist Party. The People's Party tried to attract public attention by populist initiatives, including, but not limiting to the restitution of the death penalty and criminal prosecution for male homosexuality. But the party obtained only 1.18 percent of votes by party list at the 2003 election. After that, the project was closed and its participants joined United Russia and Just Russia.

\section{Populist tactics and populist rhetoric of other parties}

Populism in Russia does not limit itself to populist parties only. Many organizations that sharply criticize populism still use populist tactics and populist rhetoric in their activities. It refers both to left (communist) and right (liberal), as well as centrist (governmental) parties. It may be said that it refers to all Russian parties with no exception. But we will highlight the most conspicuous cases only.

\section{The Communist Party of the Russian \\ Federation}

The Communist Party of the Russian Federation can be seen as a real communist party only if one takes the words of its leaders seriously. In fact, the CPRF ideology is not communism or socialism, but the same 'statist populism' that is inherent in almost all leftists in Russia. It is enough to look at the Program of the CPRF and everything will be clear.

It seems that there is no such ideological position that is not reflected in the CPRF's program. There we can find pledges of allegiance to 'socialist ideals',

22. S. Atroshenko's interview, Zavtra, 5/5/1998

23. Declaration of the Party of Pensioners, Summer of 1998, in PartArchive Database (http://www.indem.ru/pa98/).

24. V. Gartung about protest actions of the RPP in Russian cities, August 2004, in PartArchive Database (http://www.indem.ru/pa98/).

25. Declaration of the RPP, 19.01.2005, in PartArchive Database (http://www.indem.ru/pa98/) 
attempts to incorporate the Soviet period into 'the millennial history of the Russian State', references to the 'sustainable development theory, the concept of 'the Golden Billion', speculation on 'global ecological, demographic and ethnic social problems of Earth', 'the transition from the industrial society to a postindustrial, information one', 'common civilizational trends' and so on. ${ }^{26}$

The eclectic character of the CPRF ideology generated plurality of opinions about the party's position in the political spectrum. Some researchers defined the CPRF as a 'reformist' party in contrast with the 'orthodox' radical communist parties of Russia. ${ }^{27}$ Others refused to recognise it as a left party and defined the CPRF as a 'nationalist, greatpowerist and authoritarian organization which use anti-capitalist populist demagogy in the fashion of Italian Fascists and German Nazi'. ${ }^{28}$

The most interesting thing is that both these characteristics are to a certain degree correct. The CPRF is both 'left' and 'right' at the same time. It is left in socioeconomic issues, and is rather in the center and right flank of the spectrum on issues of the country's territorial division, balance of traditions and progress, order and freedom.

According to Rabotiazev's analysis, the ideology of the CPRF is a mixture of reminiscences of official Soviet ideology, national communism, narodnik socialism and the heritage of Russian conservative philosophers. ${ }^{29}$ But such assessment is correct only if we confine ourselves to 'program' speeches by the Communist Party's ideologists. Turning to all aspects of propagandistic and agitation activities of the CPRF, it would be much more correct to define the party's ideology as a kind of populism, hence its eclectics and 'anything goes' approach.

The brightest evidence of the CPRF populism was its initiative of a 'People's Referendum'. The communists could not pass a law on the referendum in the State Duma and in September 2005 carried on a campaign (an opinion poll in which anyone having such a desire was able to participate) which they called the 'People's Referendum'. People were asked about their attitude to the following proposals: to set minimum wages and minimum pension on the level not less than the cost of living; to set maximum payment for housing and utilities at not more than 10 percent of the total family income; to provide citizens with the right to choose between social benefits and money compensation; to guarantee free education and health care by law; to reduce the income tax for poor people and to increase it for the rich; to restore citizens' Sberbank deposits as of January 1, 1992; and so on. ${ }^{30}$

Surely, almost everybody who took part in the 'People's Referendum' supported all these proposals. According to the CPRF, the level of the support exceeded 90 percent. ${ }^{31}$ There is no doubt that if these issues were put to a referendum officially, the overwhelming majority of the Russian population would have voted the same way. But such things are easily declared and hardly fulfilled. The Communists understood it very well so their initiative was pure populism.

\section{Liberals - Yabloko party and the Union of Right Forces}

Since 1993, the Russian liberal movement has been split into two camps: 'the line of Gaidar' (Choice of Russia bloc, 1993-1994; Democratic Choice of Russia party, 1994-1999; the Union of Right Forces party, 1999-2007) and 'the line of Yavlinskii' (Yabloko party, since 1993 till now). The first camp had a right liberal (neoconservative) platform and advocated interests of economically successful people; the second one appealed to those liberal-minded intellectuals who were not able to support themselves without the state's aid.

Followers of Yegor Gaidar, the founding father of the Russian free market reforms were stubborn opponents of any kind of populism. They insisted that populism is the main enemy of a responsible economic policy. Such position is very risky in Russia because the population is not ready to hear that there is not enough money in the budget for higher pensions and higher salaries in the public sector.

On the contrary, followers of Grigorii Yavlinskii, a well-known Russian economist, criticized Gaidar's reforms sharply because of their 'anti-people' orientation and insisted that free market reforms should not necessarily increase but rather level down inequalities in wealth and increase the well-being of all the people. There was something populist in state-

\footnotetext{
26. Program of the Communist Party of the Russian Federation, adopted in April 1997, PartArchive Database (http://www.indem.ru/pa98/).

27. Kholmskaia (1998, p. 40).

28. Diligenskii (2000, p. 106).

29. Rabotiazhev (2007, p. 115).

30. Vestnik organizatsionno-partiinoi i kadrovoi raboty TsK KPRF, 14 (28.07.2005) (http://www.kprf-org.ru/archiv/vestnik20/vestnik20_3.html). 31. Report of the first vice-chairman of the CPRF Central Committee Ivan Mel'nikov to the plenary meeting of the CC. 28 March 2006 (http:// www. amurkprf.ru/news. php?id=242).
} 
ments of this kind. And it was not a sincere belief of Yabloko leaders but, first of all, a deliberate policy. One of the party's founders was Sergey Mitrokhin, a political analyst, who in 1991 mentioned 'ability to use populist methods of political pressure and propaganda' among the virtues of Democratic Russia (see reference 3). In my opinion, Yabloko leaders (G. Yavlinskii, S. Mitrokhin, Sergey Ivanenko, Viacheslav Igrunov) realized perfectly that the free market reforms could make the economy more effective but not more soft-hearted. They just tried to pick up the falling banners of liberalism which the followers of Gaidar could not hold.

The competition between the two camps lasted throughout the 1990s and the first half of the 2000s. In 1993, Gaidar's followers had an advantage due to support from the executive branch. They got 15.51 percent of votes by party list, while followers of Yavlinskii received 7.86 percent. But in 1995 followers of Gaidar, who had lost government support, did not overcome the five-percent threshold (3.86 percent). At the same time Yavlinskii's party obtained 6.89 percent. Nevertheless, the followers of Gaidar moved again to the fore in 1999 and received 8.52 percent of votes - against 5.93 percent for Yabloko. The 2003 election put both parties at par: neither the URF (3.97 percent) nor Yabloko (4.3 percent) overcame the five-percent threshold. As a result, both of them lost parliamentary representation.

After that, the Union of Right Forces made a full twist and demonstrated such a class of populism that the soft-populist rhetoric of Yabloko looked quite innocent in comparison. In 2004, the notorious political spin doctor Anton Bakov was invited to manage the URF electoral campaign. Bakov was famous for his shameless populism. It should be mentioned that this event was accompanied by a noisy scandal: several leaders of the party branch in Sverdlovsk Oblast (the region where Bakov came from and where he had achieved the biggest successes) left the party in protest against Bakov's entry, so unacceptable for them his political personality was. ${ }^{32}$

But it was Bakov who made it possible for the URF to elect its representatives into several regional legislatures, and left populist slogans helped it greatly. As A. Kynev wrote,

'analysis of the URF campaigns [...] allows to say that there were no signs of revival of the liberal ideology in the electoral success of the URF [...] The ideology [of the URF in the 2004 regional elections] was or- dinary social populism, promises to give everything to everybody, dissociation from the notorious "old" party leaders. In particular, protectionism for agricultural producers was promised, as well as freezing of housing and utilities tariffs, retention of some social benefits for pensioners and veterans, restoration of regular bus routes between rural communities and so on' 33

After liberal intellectual circles sharply criticized Bakov's campaigning style, the URF leadership temporarily suspended the populist tactics and returned to the old party line. The Union of Right Forces campaigned in coalition with Yabloko and other liberal parties in the second half of 2005 and in 2006. It was a pure experiment which demonstrated that when the liberals followed their traditional line they were defeated, but when they chose populist tactics they won.

Ultimately, the URF made its choice in favor of populist tactics and populist rhetoric. As a result, in March 2007 the party overcame the seven-percent threshold at the elections to seven regional legislatures. But by that time it became clear that the URF maneuvers caused great displeasure in the Kremlin. The reaction of authorities was harsh. In the regions where the results of the Rights were a bit more than seven percent, recount of votes was undertaken - after election returns had been annulled in some districts, it turned out that the URF lacked several dozens of votes to overcome the seven-percent threshold. The Kremlin let the party know that it disliked such electoral tactics.

The URF tried to use populist tactics and rhetoric again at the 2007 election to the State Duma. Campaign literature was printed in which there were promises to increase pensions significantly on the day after the election. ${ }^{34}$ But this time the authorities acted resolutely: the bulk of campaign papers (several dozens of millions of issues) was banned from circulation by the police, and when the URF complained to the General Prosecutor's Office, the order was issued to lift the ban ...within one month, i.e. after the election day. Hence, the Union of Right Forces had to campaign under not populist but anti-regime slogans. It was hopeless tactics in the existing conditions, and the URF obtained less than one percent of votes.

The Kremlin later forced the Union of Right Forces to merge with two puppet 'spoiler' parties the Democratic Party of Russia and Civil Force -

\footnotetext{
32. Andrey Selivanov ukhodit iz SPS v znak protesta protiv priniatyia v partyiu Antona Bakova, Novyi Region, 09.07.2004 (http://www.nr2.ru/ ekb/13_78925.asp).

33. Kynev (2005).

34. The author personally got a newspaper of this kind in the mail.
} 
into a single party, Right Cause by name, quite loyal to the regime.

\section{The ruling elite and the 'government party' (United Russia)}

According to straightforward logic, government parties, i.e. parties formed by the executive branch bureaucracy in order to control legislatures, should be antipodes to populist parties. But reality is more complicated. In countries with low levels of political participation, the difference between government parties and oppositional ones is insufficient in this sense. However, perhaps, the populism of government parties is not so open and provocative.

In Russia, among other things, 'governmental populism' is rather more paternalistic than imperialistic. Public officials like to present everything good as their own achievement and to explain all that is not good as a result of somebody's mismanagement and intrigues. Many governors in the 1990s tended to pose as people's champions and put all the blame on the federal government. This was one of the pretexts for repeal of gubernatorial elections in 2004.

The history of post-Soviet Russia knows many examples of such kind of populism. The most prominent of them were shown by the first Russian president Boris Yeltsin, the second president Vladimir Putin, and mayor of Moscow Yury Luzhkov.

The populism of B. Yeltsin flourished before August 1991 when he fought Gorbachev and the Soviet Union leadership. For example, during his presidential campaign in 1991, Yeltsin promised to put his head on a rail track rather than allow price rises. ${ }^{35}$ But when he assumed full power, price liberalization was his first step. After that, Yeltsin's populism shrank essentially. After several years of hard reforms, people stopped trusting his words, which made using populist rhetoric fruitless for him.

Unlike Yeltsin, who had never belonged to any political party, V. Putin became the chairman of United Russia, the main government party, in April 2007. It seems nonsense, but Putin is not a member of the party. The UR Charter was amended so that a non-member could be elected chairman of the party. It should be seen as a sign of some kind of a 'partyphobia' in the Russian ruling elite. The Russian rulers remember well enough the times when they had been the CPSU members and had to live under its permanent control - now they reject any party oversight over themselves.
When coming to power, V. Putin had the image of a responsible politician, but he did not avoid populist rhetoric. He liked to use demotic words and expressions in order to show that he was close to the man in the street. But Putin's populism was of another kind and different from than the ones demonstrated by other politicians. His populism was a populism of style, not of words. In some aspects it may be called a kind of neo-populism. As psychologist A. Sosland noted, Putin demonstrated 'splendid neo-populist style': 'To promise wonders would hardly impress somebody today. ...Today, the main requirement to neo-populist speech is the emanation of energy. ... Now the combination of severity, inclemency, on the one hand, and confidence, warmness, on the other, is needed. ... [Putin] has coped with it not so bad, up to now'.36

A different case is Moscow mayor Yury Luzhkov, one of the founding fathers of United Russia and the real boss of its Moscow city branch. He likes buzzwords and dramatic expressions. He often publicly criticizes officials of the city government, threatens them with dismissal (as a rule, without any consequences), because he knows that people like such a style of governing. Luzhkov also sharply criticizes the federal government and especially the Ministry of Finance because of its 'avarice' towards Moscow and its 'monetarist' financial policy. Given strong anti-immigrant and homophobic moods of the Moscow population, Luzhkov vows never to permit gay rallies in the city and regularly demands cutting quotas for labor force from the former USSR republics. He came out with eccentric foreign policy initiatives. For example, he fights for the independence of Crimea from Ukraine, transfer of Sevastopol to Russia, channeling of Siberian rivers to Central Asia, and so on. He argues against the Uniform National Examination, reforms of higher education along the lines of the Bologna process, and genetically modified products, because elderly voters, his core electorate, distrust all that.

There are (or were) other bright populists among governors: Aman Tuleiev (Kemerovo Oblast), Evgenii Nazdratenko (Primorskiy Krai), Nikolai Kondratenko (Krasnodar Krai) and others. Some of them have already been dismissed but others continue to rule their regions (A. Tuleiev). Their rhetoric is quite similar to Luzhkov's. It is interesting that some of these governors had been Communists in the 1990s. Some of them (Tuleev, for instance) walked over to United Russia in 2000, but others (Kondratenko) preferred to leave their posts but not to change their beliefs. 


\section{Conclusion}

As we can see, populism in post-Soviet Russia has some features similar to Latin American populism and some which distinguish it from the latter. Thus, the common characteristics of the Russian and Latin-American populism are charismatic leadership, political personalism, priority of leadership over institutions, adherence to national development concepts and anti-globalization movement. The difference lies in the interpretation of 'anti-imperialism': the Russian populism is anti-American and anti-Western but not anti-imperialist in general. The Russian populists are, as a rule, extreme Russian imperialists and, to a certain degree, nationalists.

Besides, the Russian populism may be called statist and paternalistic. There is almost no difference between left (socialist) and right (nationalist and conservative) populisms in Russia. The overwhelming majority of the Russian leftists are conservative, statist and nationalist while the overwhelming majority of nationalists and conservatives are stubborn anti-capitalists. Non-socialist conservatives and non-conservative socialists (communists) are marginal in the country.

Moreover, many traditional ideologies - such as communism and nationalism - are, in fact, varieties of 'state populism' in today's Russia. It may be said that populism embraced the whole Russian political spectrum, including even those sectors which always positioned themselves as anti-populist (right liberals, for example).

Nevertheless, there is only one stable populist party in post-Soviet Russia - the Liberal Democratic Party of Russia. It has existed since 1991, and the charisma of its leader V. Zhirinovskii is the only factor of its viability. His political instinct allows the party to reflect adequately changes in voters' mood. All other populist projects failed - most of them by their own fault, others not without a 'little help' from the authorities. Moreover, the reason why Rodina, the Russian Party of Pensioners and, to a certain degree, the Union of Right Forces left the political scene was that they used populist tactics and populist rhetoric so successfully that they 'stole' votes from 'government-owned' United Russia.

Now 'statist populism' is the only ideology $\mathrm{y}^{37}$ which can attract more or less wide circles of voters to the Russian opposition. 'Pure' ideologies, such as socialism (communism), liberalism, conservatism, or nationalism, have no chances to be popular. The main problem of the Russian political life is that the authorities have learned to use populist rhetoric not worse than opposition. However, the historical experience shows that when populist opposition substitutes populist rulers, the situation does not change in general. Those politicians who want to transform Russian politics should think first of all of how to break out of the vicious circle of ceaseless rotation of populists.

37. Following G. Musikhin (2009, p. 51), we recognise that populism is a 'fragmented' and 'uncompleted' ideology which doesn't borrow positions from other ideologies but adds itself to them. 


\section{References}

BIRIUKOV, N. I.; SERGEIEV V. I. Stanovlenyie institutov predstavitel'noi vlasti v sovremennoi Rossii (The Formation of Representative Power Institutes in Contemporary Russia). Moscow: Izdatel'skii Servis, 2004.

DILIGENSKII, G. G. O politicheskom rynke i ratsional'nom vybore $\mathrm{v}$ rossiiskikh uslovyiakh (About a Political Market and a Rational Choice in the Russian Situation). Polis, n. 2, p. 105-107, 2000.

GOLOSOV, G. V. Partiynyie systemy Rossii $i$ stran Vostotschnoi Evropy (Party Systems of Russia and Eastern European Countries). Moscow: Ves' mir, 1999.

. Rossiiskaia partiinaia sistema i regional'naia politika, 1993-2003 (The Russian Party System and Regional Politics). St. Petersburg: European University in St. Petersburg, 2006.

KHOLMSKAIA, M. R. Kommunisty Rossii: facty, idei, tendentsii (infomatsionno-analiticheskii obzor) (Communists of Russia: Facts, Ideas, Trends. Information and Analytical Survey). Moscow, 1998.

KYNEV, A. Vybory regional'nykh zakonodatel'nykh sobranii oseni 2004: izbiratel ischet novykh geroiev (Elections to Regional Legislatures in the Fall 2004: A Voter Looks For New Heroes). Available at: <http://www.indem.ru/ idd2000/anal/Kinev/OsenZS05.htm>. Accessed on: 10 abr. 2010.

MIKHAILOVSKAIA, Ye. et al. (Eds.). Partyia nomer chetyre. 'Rodina' i okrestnosty (The Party n. 4. 'Rodina' and the Vicinity). Moscow: Panorama Center, 2006. Available at: $<$ http://www.orodine.ru/kniga/party4.html)>. Accessed on: 10 abr. 2010.

MITROKHIN, S.S. Dvizhenyie "Demokraticheskaia Rossyia" kak partiinaia mashina (Democratic Russia Movement as a Party Machine), Panorama, n. 1, 1991. Available at: <http://www.panorama.ru/gazeta/1-30/ p28mitr.html>. Accessed on: 10 abr. 2010.

MUSIKHIN, G.I. Populism: strukturnaia kharakteristika politiki ili "uscherbnaia ideologyia"? (Populism: Structu- ral Characteristic or "Defective Ideology"?), Politeia, n. 4, p. 40-53, 2009.

PETROV, N. Alexander Lebed v Krasnoyarskom kraie (Alexander Lebed in the Krasnoyarsk Krai). Moscow: Carnegie Moscow Center, 1999. Available at: <http://www.carnegie.ru/ru/pubs/books/volume/102808.pdf>. Accessed on: 10 abr. 2010.

PRYBYLOVSKII, V.V. Yeltsin Boris Nikolaevich. 2005 Available at: <http://www.anticompromat.org/eltsin/eltsinbio.html>. Accessed on: 10 abr. 2010.

Slovar oppozitsii. Novyie politicheskyie partii i organizatsii Rossii (A Dictionary of Opposition. New Political Parties and Organizations of Russia). In: Sostoianyie strany. Analiticheskyie vestniki informatsionnogo agentstva Postfactum, n. 4/5, 1991.

RABOTIAZHEV, N.V. Istoriosofyia i geopolitika rossiiskogo konservatisma: opyt analiza (The Historiosophy and the Geopolitics of the Russian Conservatism: An Attempt of Analysis), Politeia, n. 2, p. 103-118, 2007.

SAKWA, R. Russian Nationalism and Democratic Development. In: Bowker, M. and Ross, C. (Eds.). Russia after the Cold War. Harlow: Pearson Education Limited, 2000. SHEINIS, V.L. Vzliot i padenyie parlamenta. Perelomnyie gody $v$ rossiiskoi politike (1985-1993) (The Rise and Fall of the Parliament. Turnaround Years in Russian Politics, 1985-1993). Moscow: Carnegie Moscow Center, INDEM Foudation, 2005. v. 2.

SOSLAND, A.I. Putin: razgadka sekreta (Putin: The Answer to an Enigma). 2007. Available at: <http://psyfactor. org/lib/putin2.htm>. Accessedon: 10 abr. 2010.

YANG, M.; LAUNER, M.; LIKHATCHIOVA, I.; WILLIAMS, D.; ISHIYAMA, J. Polititcheskaya argumentatsiya partii na vyborakh v Gosudarstvennuyu Dumu: uroki ysvoyenniye i neusvoyenniye (Parties' Political Argumentation at the State Duma Elections: Lessons Learnt and Not Learnt). Politeia, n. 2, p. 32-44, 1997. 


\section{Táticas e retóricas populistas em partidos políticos da Rússia pós-soviética}

\section{Resumo}

O artigo de Yu. Korguniuk (Rússia) dedica-se a vários aspectos do populismo nas táticas e retóricas dos partidos políticos na Rússia pós-soviética (desde 1990). O autor discute esses aspectos nas atividades dos partidos políticos que podem ser chamados de populistas sem sombra de dúvida, bem como em partidos que usam táticas e retóricas populistas, mas não podem ser considerados populistas, no sentido pleno da palavra. Em sua opinião, o populismo na Rússia pós-soviética apresenta características similares ao populismo latino-americano e outras que o distinguem desse último. As características comuns são a liderança carismática, o personalismo político, a prioridade da liderança sobre as instituições, a aderência aos conceitos de desenvolvimento nacional e ao movimento anti-globalização. A diferença reside na interpretação do 'anti-imperilalismo': o populismo russo é antiamericano e antiocidental, mas não anti-imperialista em geral. Os populistas russos são, em regra, extremamente imperialistas e, em certa medida, nacionalistas. $\mathrm{O}$ populismo russo também pode ser chamado de estatista e paternalista: não há quase nenhuma diferença entre o populismo da esquerda (socialista) e da direita (nacionalista e conservadora). Além disso, o autor argumenta que muitas ideologias tradicionais - como comunismo e nacionalismo - são, de fato, variedades do "populismo de estado" na Rússia hoje. Na conclusão, ele afirma que o populismo abarca todo o espectro político russo, incluindo mesmo setores que sempre se posicionaram como antipopulistas.

Palavras-chave: Rússia pós-soviética, partidos políticos, populismo.

\section{Tácticas y retóricas populistas en los partidos políticos de la Rusia post- soviética}

\section{Resumen}

El artículo de Yu. Korguniuk (Rusia) se dedica a varios aspectos del populismo en las tácticas y retóricas de los partidos políticos en la Rusia post-soviética (desde 1990). El autor discute esos aspectos en las actividades de los partidos políticos que pueden ser llamados de populistas sin ninguna duda, bien como en partidos que usan tácticas y retóricas populistas pero no pueden ser considerados populistas en el sentido pleno de la palabra. En su opinión, el populismo en la Rusia post-soviética presenta características similares al populismo latinoamericano y otras que lo distinguen de ese último. Las características comunes son el liderazgo carismático, el personalismo político, la prioridad del liderazgo sobre las instituciones, la adhesión a los conceptos de desarrollo nacional y al movimiento antiglobalización. La diferencia reside en la interpretación del 'anti-imperialismo': el populismo ruso es antiamericano y antioccidental, pero no anti-imperialista en general. Los populistas rusos son, en regla, extremos imperialistas rusos y, en cierta medida, nacionalistas. El populismo ruso también puede ser llamado de estatista y paternalista: no hay casi ninguna diferencia entre el populismo de la izquierda (socialista) y el de la derecha (nacionalista y conservadora) en Rusia. Además, el autor argumenta que muchas ideologías tradicionales -como el comunismo y el nacionalismo- son, de hecho, variedades del 'populismo del estado' en Rusia hoy. El autor concluye que el populismo abarca todo el espectro político ruso, incluyendo sectores que siempre se posicionaron como antipopulistas.

Palabras clave: Rusia post-soviética, partidos políticos, populismo.

Data de recebimento do artigo: 17/4/2010

Data de aprovação do artigo: 4/6/2010 